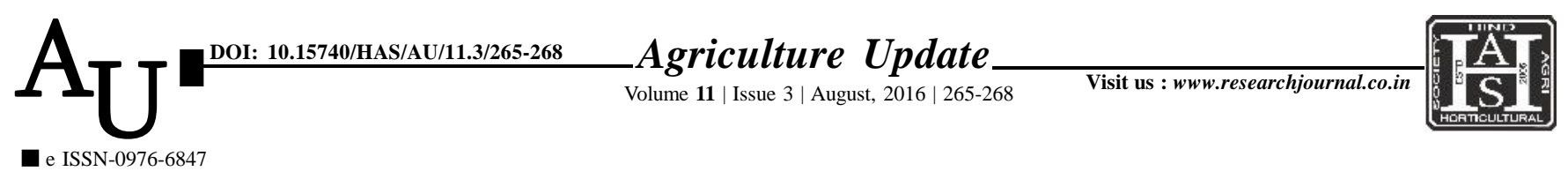

\title{
Research Article: Constraints faced by farmers of Kathua district in adoption of marigold production technology
}

\author{
口 NEERJA SHARMA AND ANAMIKA JAMWAL
}

Article Chronicle : Received : 16.11.2015;

Revised :

30.06.2016;

Accepted :

11.07.2016

\section{Key Words : \\ Constraints, Production technology, Marigold, Adoption}

SUMMARY : Marigold is an important commercial crop among all flower crops. Its flowers are available year around. Marigold flowers are used for various purposes like : worshipping, as cut flower, for beautification of beds and borders in lawns, in textile industry and for medicinal purpose. Marigold cultivation is highly commercialised now a days. But still area and production of marigold under Jammu province is less due to several factors. The present study was undertaken in Kathua district of Jammu and Kashmir to investigate the constraints faced by marigold growers during production and marketing of marigold. This district consists of eight blocks from which block Hiranagar, Barnoti, and Kathua were selected purposively. From each block four villages and from each village thirty farmers were selected, where the farmers were having largest area under marigold cultivation. A random sample of 120 farmers were drawn by randomization. A structured interview schedule was prepared for collection of data with a view to study various aspects regarding marigold cultivation. The data were collected through pre structured interview schedule and statistical procedure were employed to analyse the data. The study highlighted that majority of farmers had medium knowledge as well as medium level of adoption of marigold production techniques. The study further highlighted that majority of farmers were not adopting marigold cultivation due to various constraints like input constraint, technical constraints, economic constraints, extension constraints and marketing constraints. The major constraints expressed by marigold grower in each group of constraints were lack of timely availability of good quality seed material, lack of knowledge about production technology, high cost of hybrid seeds, lack of information through mass media and lack of co-operative institutions for marketing.

How to cite this article : Sharma, Neerja and Jamwal, Anamika (2016). Constraints faced by farmers of Kathua district in adoption of marigold production technology. Agric. Update, 11(3): 265-268, DOI : 10.15740/HAS/AU/ 11.3/265-268.
Author for correspondence :

\section{NEERJA SHARMA}

Krishi Vigyan Kendra, Sher-E-Kashmir University of Agricultural Sciences and Technology of Jammu, KATHUA (J\&K) INDIA

Email: neerja1975@

gmail.com

See end of the article for authors' affiliations 